\title{
RECKITT AND SONS, LTD., NEW BIOLOGICAL RESEARCH LABORATORIES
}

$\mathrm{O}^{\mathrm{N}}$ October 9, an open day was held at the Pharmaceutical Research and Dovolopment Laboratories of Rockitt and Sons, Ltd., Hull. This was attondod by more than sixty distinguished medical and other scientists from the universities, the hospital servicos, rosearch institutions, Govornment departments and the pharmaceutical industry, who toured the new Biological Research Laboratories as well as somo of tho older-established laboratorios.

In his speech of welcome, Mr. J. H. Chapman, chairman, mentioned that the occasion gave him the opportunity of expressing tho approciation and thanks of the Company, and of the senior members of the scientific research staff, to those guesta who had gonorously given the Company the benefit of their advice and guidance, whother in regard to the new Biological Research Laboratories or in regard to sciontific research over the years.

Sir Robert Robinson thanked the Company for their hospitality and congratulated them on the excellence of their biological research facilitios. Sir Robert roforred, in passing, to the Joint Rosoarch Association betweon Messrs. J. F. Macfarlan and Co., Ltd., of Edinburgh and Messrs. Reckitt and Sons, Ltd., and montioned that Dr. K. W. Bentloy, Dr. R. E. Listor, and Dr. D. G. Hardy, who were members of the joint research team, had succoodod in uncovoring a serios of drugs whioh oontained compounds with unprecedented analgesic and antitussive potency. Sir Robert expressed pleasure that Dr. K. W. Bentloy, who was one of his old research studonts, was associated with this work.

'The drugs briefly referred to by Sir Robert Robinson in his speech after the luncheon were described by Dr. K. W. Bentley and Dr. D. G. Hardy in the Proceedings of the Chemical Society of July 1963, p. 220. Details of pharmacological evaluation hy Dr. R. E. Listor aro oxpocted to be published in the near future. The drugs in question are dorived from thebaine, an alkaloid which occurs naturally in opium, which has been rogardod in tho past as a thora. peutically valueless by-product of morphine and codeine manufacture. 'The series uncovored by those rescarch workers is extensive, and not only have somo members unprecedented analgesic and antitussive properties combined with favourable therapeutic indices but they possess other interesting offects on the central nervous system. The work is insufficiently advanced to speculate on the full potential interest of these compounds, which are patented. Their ovaluation from the pharmacological and clinical point of view, and particularly from the drug safety point of viow, is boing pursuod. Naturally, this is a lengthy and time-consuming process, and it is likely that at least two to three years may elapse before this exciting research might rosult in now drugs boing mado available to the medical profession.

'Tho new Biological Research Laboratories of Reckitt and Sons, Ltd., are un oxtension of tho oxisting laboratories which were built in 1956 to replace temporary accommodation which had been occupied from 1942 when the very old-establishod laboratories, togethor with library and archives, were totally destroyed by onemy action.

The now Biologieal Research Laboratories have been built, furnished and oquipped at a cost of moro than $£ 250,000$, and occupy a total of 40,000 sq. ft. distributed betweon seven floors. 'Ihese laboratories together' with the Bacteriological Rosoarch Laboratory (which is situated in the adjacent 1956 laboratory block) omploy at present moro than 90 porsons, of whom 37 are university graduates.

Tho resonath disciplines ombracod inoludo: pharms. cologs, biochemistry, synthotic organic chomistry, chomical pathology, histopathology, experimental animal facilities, radioactivo isotopo investigations. The arrangement of the laboratories is necessarily a compromise botwoon the noeds of the discipline and the characteristics of the site. The solution arrived at ostablishes the radioactive isotope laboratory on the ground-floor; whorens, because of the congested nature of the site, the experimental animals are ostablishod on the two top floors and on the roof. Other laboratories are arranged betweon thoso, and the arrangement has proved eminently successful in practice.

The design of each floor is such that the contral areas aro occupiod by utility rooms within a corridor for circulation of personnel. Peripherally from the corridor lie the working laboratories giving maximum access to daylight. Because of the relatively high solid matter pollution of the air in the industrial vicinity no windows can be oponod. A plenum system supplies laboratories and corridors with filtered, attomperated air, and heat losses from the building in cold weather are compensated by a low-pressure hot water circulating system. The extract from the radioactivo isotope suite is on separate system vented at high level.

The experimental animal rooms are ventilatod by an entiroly separate plant utilizing stand-by units, including a stand-by olectrodo boilor, dosigned to minimize risks of either disaster, or interference with experimental animal work, through failure of any vulnerable part of the ventilation plant. The wholo suite of experimental animal rooms is designed to give maximum flexibility in uso as betwoen animal spocies, on one hand, and breoding, holding or experimental requirements on the other hand. Each experimental animal room may be held at a selected temperature, $\pm 1^{\circ} \mathrm{F}$, within the approximate range of $65^{\circ}-73^{\circ} \mathrm{F}$. The design of the ventilation plant is such that the upper limits will never be exceeded, while it is estimated from past local climatological data that control of the lower limits may bo partially lost only on two days, on the avorago, in a ten-year period on occasions when external conditions may simultaneously be very hot and very humid. Thus, the heat-stroke disasters which wiped out a number of experimental animal colonies in Britain, with the research costs implicitly invosted in them, will, it is hoped, not be repeated. Such an arrangemont is also in conformity with humane considerations. The relative humidity within all animal rooms will be within the range $45-75$ per cent, the actual figure boing dependont on external ambient conditions. The upper limit generally maintains comfort for cxperimental animals and animal tochnicians alike; while the lower limit avoids the dovelopment of ring-tail in rats and will, it is expected, reduce the liability to acuto respiratory infoction in colonits which may follow excessive dehydration of the respiratory mucosa. All oxporimontal animal rooms are designed for the ready maintenance of the highest standards of hygiene by independent sterilization with germicidal washes and/or fumigation. A standard system of cage racks on castors has been adopted for flexibility. An autometic cage washing machine has been installed and an autoclave will sterilizo two racks, complote with cages, simultaneously.

At presont, rats and mice are bred from specific pathogen-free animals which are obtained from external sources and theso stooks aro ruaintained for as long as possible in conditions of maximum possible cleanlinoss. The systom will be reviewed periodically in the light of evonts.

The air-intake filtor systems both to laboratories and to oxperimontal animal houses are rated to extract all 
particles in excess of $5 \mu$; but the filtered air supplied to operating theatres is additionally passed through bacteriological filters. In the radioactive experimental animal room provision is made for air extract from each individual metabolism cage in order to avoid cross-contamination by ${ }^{14} \mathrm{CO}_{2}$.

All the widely used services are brought into the building in a central plant room and thence distributed by commodious vertical ducts, to which there is ready access at all floor-levels, at each of the four corners of the building. Because of the known vagaries of centralized vacuum systems due to extreme fluctuations in demand and the sensitivity of experimental apparatus to relatively minor fluctuations, vacuum is generated locally as required throughout the new research laboratories.

As annexes to the main pharmacology laboratory there are laboratories for isolated organ bath screening procedures and for whole-animal experimental procedures. There is also a constant-temperature laboratory for experimental procedures in which temperature changes make an appreciable contribution to total variances. A further laboratory is both sound-proofed and electrically screened. Thus, it may be used either for experimental animal behavioural investigation or for electro-physiological experimentation.

The radioactive isotope laboratory, for reasons of safe and orderly use by appropriately trained scientific staff, is under the supervision of the senior biochemist, since his department are main users for metabolism and detoxification investigations. The electrically screened counting room is as remote as possible from the baryta-concrete protected store and 'hot' laboratory. Expert advice has been found to be divided in regard to electrically screening the counting room. Because of the low counts common in biological work, the uncertain control of interference near the site for the future, the relatively low cost and freedom from dislocation and hazard by building-in screening during construction rather than later, the decision was taken to build in screens during construction. Bearing in mind the rapid advances in the use of radioactive isotopes in biological research, the fact that the radioactive isotope laboratory is intended to provide a service to the group with its manifold interests, and the estimate of a useful 25-year life for the block, over-provision in respect of space and safety facilities has been deliberately made relative to anticipated needs in the near future throughout planning and construction.

Already existing laboratories support the work of the new Biological Research Laboratories. These include: chemical analysis; micro-elemental analysis with flame photometry; spectroscopy (ultra-violet and infra-red); chromatography (vapour phase, thin layer, paper electrophoresis, etc.). All research workers draw strength and confidence from the well-established Statistical Department in respect of experimental planning and analysis. After the 1942 bombing, a complete library and information service has had to be re-assembled and this has been functioning efficiently, especially during the past decade or so.

Messrs. Reckitt and Sons, Ltd., one of the six main operating companies of the Reckitt and Colman Holdings Limited Group, are well established in the pharmaceutical field with 'Dettol', the antiseptic developed in their Bacteriological Research Laboratories and introduced to the medical profession in 1932; with 'Disprin'-the first stable, soluble preparation of aspirin introduced at the London Medical Exhibition in 1948 as the first-fruit of post-war research, and the therapeutically related 'Codis' and 'Cafdis'; with the stable non-nauseating antacid preparation, 'Alcin'. Through the Joint Research Association with J. F. Macfarlan and Co., Ltd. (for a review of the historical setting in which this Company was founded at the end of the eighteenth century see: "William Gregory, M.D., F.C.S.: 1803-1858", by G. Colman Green, Nature, $157,465: 1946)$, there is the promise of fruition of scientific research in novel ways in the potent analgesic field (see K. W. Bentley and D. G. Hardy (Proc. Chem. Soc., 220; July 1963), as mentioned earlier in this article. With the new Biological Research Laboratories now available it is hoped that the Company's repute and activities in the pharmaceutical field throughout the world will be both consolidated and extended.

G. Colman Green

\section{THE CASACCIA CENTRE FOR NUCLEAR STUDIES}

$\mathrm{T}$ HE Casaccia Centre for Nuclear Studies, of the Comitato Nazionale per l'Energia Nucleare, Rome, comprises a complex of facilities and laboratories concerned with research in the various sectors connected with the production and uses of nuclear energy. The Centre occupies an area of about 160 acres: it is divided into nine areas, each assigned to a specific activity. The subdivision into areas was made with regard to the possibilities of future expansion of the Centre, space being allowed for further developments.

The $R C-1$ reactor. The $R C-1$ (Reattore Casaccia-1) reactor, the maximum power of which is of $100 \mathrm{~kW}$, is the Centre's major installation.

The reactor core, surrounded by a graphite reflector, is a complex of homogeneous fuel-moderator elements made up by a ternary alloy of 20 per cent enriched uranium $\left({ }^{235} \mathrm{U}\right)$ and zirconium hydride. The reactor is contained in a pit about $19 \mathrm{ft}$. deep filled with demineralized water, which performs a two-fold function as shield and moderator. The neutron moderation function is performed also by the zircon hydride. A concrete tank located near the main reactor pit is used for experiments on the attenuation of neutrons and $\gamma$-rays. 'The reactor's experimental equipment also comprises: a thermal column, four horizontal and one vertical irradiation channels, a pneumatic pipe for the fast transfer of the various short-lived isotopes and a revolving rack which makes it possible to irradiate forty samples simultaneously. In the course of the modification work a second vertical channel was installed in the portion of the thermal column projecting inside the pit.

Applied Nuclear Physics Laboratory. The research activity of the applied nuclear physies laboratory is conducted along two lines: experimental and theoretical.

For experimental research, the laboratory uses the $R C-1$ reactor and the Van de Graaff pulsed accelerator. Among theoretical research projects of particular interest are investigations on the slowing and thermalization of neutrons in organic moderators. These investigations fit into the framework of one of CNEN's major objectives, that is, the all-Italian development and construction of an organic-moderated reactor, which will provide information for the subsequent development of power reactors of this kind (Pro).

Reactor Engineering and Servomechanisms Laboratory. This laboratory is concerned with all problems connected with the designing and construction of nuclear reactors or installations.

Among its projects special mention should be made of the nuclear plant simulator, an electronic manipulator for radioactive premises, one set of the standard equipment for the control of nuclear reactors (SCIN Project), an experimental moderated and organic zero-power reactor and a set of experimental circuits built for the testing of 